\title{
Natural molecules having anti-SARS-CoV activity - cannot they be effective against SARS-CoV-2?
}

\author{
Deepak Kumar Semwal $^{1, *}$, Ashutosh Chauhan ${ }^{2}$, Ruchi Badoni Semwal ${ }^{3}$, \\ Debabrata Sircar ${ }^{4}$, Partha Roy ${ }^{4}$ and Jörg Lehmann ${ }^{5}$ \\ ${ }^{1}$ Department of Phytochemistry, Faculty of Biomedical Sciences, Uttarakhand Ayurved University, Harrawala, Dehradun 248 001, India \\ ${ }^{2}$ Department of Biotechnology, Faculty of Biomedical Sciences, Uttarakhand Ayurved University, Harrawala, Dehradun 248 001, India \\ ${ }^{3}$ Department of Chemistry, Pt Lalit Mohan Sharma Government Postgraduate College, Rishikesh 249 201, India \\ ${ }^{4}$ Department of Biotechnology, Indian Institute of Technology Roorkee, Roorkee 247 667, India \\ ${ }^{5}$ Department of Therapy Validation, Fraunhofer Institute for Cell Therapy and Immunology IZI, Perlickstr. 1, 04103 Leipzig, Germany
}

In the current scenario, developing treatments, identifying cures and formulating intervention strategies to fight against the COVID-19 outbreak, have become the major concern for researchers globally. Several studies have confirmed the molecular pathway of COVID-19 virulence that involves activation of proteins like angiotensin-converting enzyme 2 (ACE2), angiotensin (AT) receptor which is mainly AT1, and transmembrane protease serine 2 (TMPRSS2). Since the virus needs the involvement of these proteins, over and above its spike protein, for activation and infecting the host, it is obvious that targeting or blocking the activation of these molecules may play a critical role in the development of therapeutics for the cure and management of COVID-19. Many studies have been reported and several are ongoing to find a cure using these molecules as a target. While initially COVID-19 was thought to be affecting the human respiratory system, recent shreds of evidence indicate that this infection can reach beyond the lungs. It can invade and rampage almost all the organs in the body, and 'cytokine storm' is considered to be responsible for this. The reason for disease severity is not what matters anymore now, everyone is hoping for a cure soon enough. Therefore, there is an urgent need to search for some novel drugs/chemicals. Towards this end, natural products can contribute immensely since they have a long history of usage for the cure and management of various ailments, including viral infections. Various natural products (mainly from plants) have structural similarities to the molecules which by AT has been shown to interact with targets used by COVID-19 during its infection. This is indeed a positive indication for the development of natural products-based therapeutics. This aspect, therefore, warrants serious consideration for the cure and management of the COVID-19 pandemic.

\footnotetext{
*For correspondence. (e-mail: dr_dks.1983@yahoo.co.in)
}

Keywords: Coronavirus, cure and management, herbal medicine, natural products, pandemic.

CORONAvirus ( $\mathrm{CoV}$ ) is a single-stranded RNA (ssRNA) virus of the Coronaviridae family which is comprised of several pathogenic species that are mainly responsible for upper respiratory and gastrointestinal tract infections in humans and other mammals ${ }^{1}$. Particularly, the human coronavirus (HCoV), such as 229E, OC43, NL63 and HKU1, may cause severe acute respiratory syndrome (SARS) and hence is called SARS-CoV; it is spreading world over among the human population ${ }^{2}$. SARS-CoV-1 and Middle East Respiratory Syndrome (MERS)-CoV in 2003 and 2012 respectively, were introduced as a global threat with a large number of casualties $^{3,4}$.

The recently introduced novel coronavirus (SARSCoV-2 or 2019-nCoV) from Wuhan, China, caused the COVID-19 outbreak which was declared as a global pandemic by World Health Organization (WHO). It has spread to 200 countries and caused more than 477,000 deaths across the globe as on 24 June 2020. Similar to the earlier infections caused by SARS-CoV, MERS-CoV and Ebola, COVID-19 is incurable during its outbreak and thus, the scientific and medical fraternity has succumbed to this disease. The only procedure being adopted is to treat the infection symptomatically and to stop the spread of this virus through social distancing, lockdown or curfew. Hence, the discovery of a new drug/vaccine for $2019-\mathrm{nCoV}$ is an urgent need of the hour.

The present work aims to review the selected anti-SARS-CoV molecules from natural origin and their possible role against SARS-CoV-2. Among 53 natural anti-CoV molecules chosen using different search engines like Scopus and PubMed, a total of 24 most effective molecules were selected for this study. Studies based on molecular docking without in vitro/in vivo experiments are rarely included here. 


\section{Structural similarity between SARS-CoV and SARS-CoV-2}

CoV has seven strains, of which three are highly pathogenic, viz. SARS-CoV-1, MERS-CoV, and SARS-CoV2 , and caused severe $\mathrm{CoV}$ pandemic disease ${ }^{5}$. These have clinically important structural proteins such as spike (S), membrane (M), envelope (E) and nucleocapsid (N) (Figure 1). Some of the viruses, including SARS-CoV also have hemagglutinin esterase (HE) glycoprotein ${ }^{6}$. These are RNA viruses and their genome codes for seven genes that are conserved in the order of ORF1a, ORF1b, $S$, $O E F 3, E, M$ and $N$ in $5^{\prime}-3^{\prime}$ direction. The gene $O R F 1 a / b$ produces two viral replicase proteins that are polyproteins (PP1a and PP1ab) ${ }^{7}$. Sixteen other mature nonstructural proteins (NSPs) arise from further processing of these two polyproteins. The NSPs take part in different viral functions, including formation of the replicase transcriptase complex. The remaining genome part of the virus encodes the mRNA which produces structural proteins, i.e. S, E, M, and $\mathrm{N}$ and other accessory proteins ${ }^{7}$. Another important envelope-associated protein which is expressed by only some strains of $\mathrm{CoV}$ is the HE protein ${ }^{8}$. The RNA genome of $\mathrm{CoV}$ is packed in the nucleocapsid protein and further covered with an envelope.

The SARS-CoV-2 has approximately 79\% genome sequence identity with SARS-CoV and 50\% with MERS$\mathrm{CoV}$ (ref. 9). A study using sequence-based comparison confirmed that $\mathrm{M}, \mathrm{N}$ and $\mathrm{E}$ proteins of SARS-CoV-2 and SARS-CoV have over $90 \%$ genetic similarity, while $\mathrm{S}$ protein of SARS-CoV and SARS-Cov- 2 has $76 \%$ similarity ${ }^{10}$. Besides, homology modelling showed that SARS-CoV-2 also uses ACE2 receptor in humans for infection, similar to SARS-CoV (ref. 11). Recently, it has been demonstrated that human recombinant soluble ACE2 can significantly block early stages of SARS-CoV-2 infections ${ }^{12}$. Despite

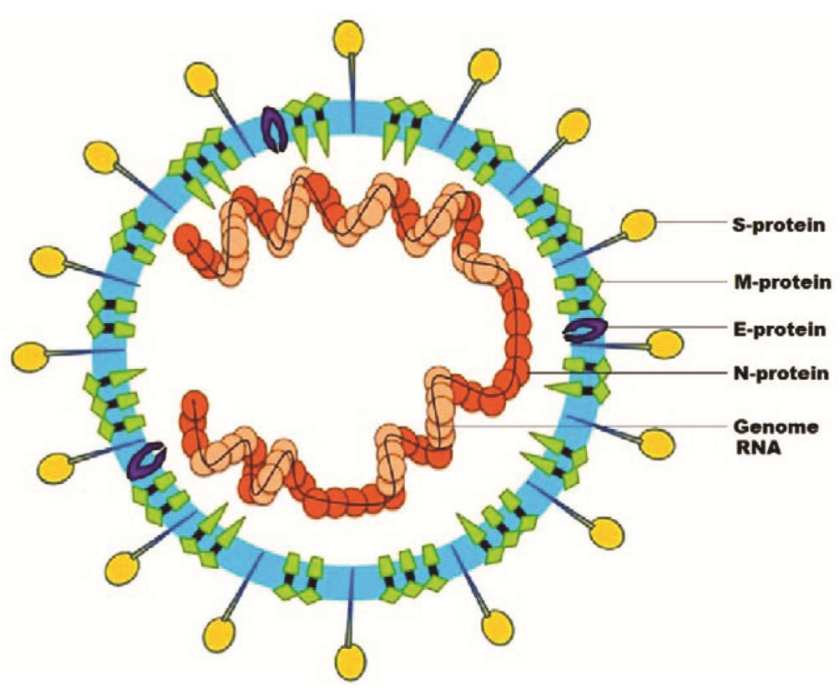

Figure 1. Structure of SARS-CoV (reproduced with permission from Li et al. ${ }^{13}$ ). the name and genetic similarities, SARS-CoV-2 shows genetic and clinical differences with SARS-CoV. The Sprotein found in SARS-CoV-2 is longer than that in SARS-CoV, and the receptor-binding regions of these viruses are completely different. Moreover, SARS-CoV nucleocapsid $(\mathrm{N})$ protein can neutralize the immune response of the host, acting as an antagonist to the action of interferon (IFN)- $\gamma$, and it is still not known if the SARS-CoV-2 N-protein has the same ability. If not, this would partly explain why SARS-CoV has a higher mortality rate than SARS-CoV-2 (ref. 13). Similarly, the R0 (R through) of SARS-CoV-2 is two- to three-fold higher than that of SARS-CoV. Usually, a high R0 is associated with highly diffusible infections, which at the same time have a long incubation period, and characterized by mild to moderate symptoms, or latent infection associated with a low mortality rate ${ }^{14}$. SARS-CoV-2 receptor binding motif (RBM) contains structural changes in the hACE2-binding ridge, largely caused by a four-residue motif (residues 482-485: Gly-Val-Glu-Gly). This structural change allows the ridge to become more compact and form better contact with the N-terminal helix of hACE2 compared to SARS-CoV. Phe486 from the SARS-CoV-2 RBM can insert into a hydrophobic pocket. The corresponding residue in the SARS-CoV RBM is leucine, which likely forms a weaker contact with hACE2 due to its smaller side chain $^{15}$. These hotspots on hACE2 are critical for coronavirus binding, because they involve two lysine residues that need to be accommodated properly in hydrophobic environments. Neutralizing the charges of the lysine residues is key to the binding of coronavirus receptor-binding domain (RBD) to hACE2. SARS-CoV-2 RBM has evolved strategies to stabilize the two hotspots; Gln493 and Leu455 stabilize hotspot-31, whereas Asn501 stabilizes hotspot353. Therefore, biochemical data confirm that SARSCoV-2 RBD has significantly higher hACE2-binding affinity than that of SARS-CoV, and that the above structural features of SARS-CoV-2 RBM contribute to the high hACE2-binding affinity of SARS-CoV2. Thus, both structural and biochemical data reveal that SARS-CoV-2 RBD recognizes hACE2 better than SARS-CoV RBD.

\section{Important targets for drug development against SARS-CoV-2}

The majority of medicinal plants contain many different compounds and most of them are quite complex. Plants contain a variety of materials having medicinal properties. Majority of them includes polysaccharides, polyphenols, tannins, saponins and various other complex materials that modulate and modify the effects of any 'active principles'. It has been shown that the extract of whole plant does not mimic the isolated and purified constituents of the herbs. According to the literature, it is considered that the whole plant consists of various parts in most cases of 
higher efficacy compared to individual components ${ }^{16}$. Therefore, a thorough screening of natural products-based drug-like molecules may lead to the development of therapeutics which could be used in the cure and management of COVID-19.

In the past decades, mainly after the SARS-CoV outbreak in 2003, scientists the worldover studied various targets to develop new antiviral drugs, which include the inhibition of essential proteases, helicase and viral proteins ${ }^{17}$. These enzymes are critical for the synthesis of RNA and protein of the virus. Amongst them, one of the important groups is non-structural proteins (NSPs), which are involved in transcription, translation, protein synthesis, processing and post-translational modification, virus replication and infection of the host. Similarly, helicase (NSP13), a multi-functional protein which includes the $\mathrm{N}$-terminal metal-binding domain and helicase domain, is a necessary component for the replication of CoV. NSP13 can unravel double-stranded (ds) DNA and RNA along the $5^{\prime}-3^{\prime}$ direction in an NTP-dependent manner ${ }^{18}$. Other groups of proteins are structural proteins of the virus, responsible for binding to human cell receptors.

Spike is the main structural protein that interacts with the host by binding to host cell receptors in order to mediate virus invasion and determine viral tissue or host tropism $^{19}$. Spike is cleaved into $\mathrm{S} 1$ and $\mathrm{S} 2$ by the host cell protease like type-II transmembrane serine protease. The S1 subunit binds with the host cell surface receptors and the S2 subunit mediates virus-cell and cell-cell membrane fusion. There are some other proteins such as NSP1, NSP3c and ORF7a, called virulence factors which interfere with the innate immunity of the host. NSP1 interacts with host $40 \mathrm{~S}$ ribosomal subunit that induces specifically host mRNA degradation and also inhibits type-I interferon production ${ }^{20}$. Similarly, NSP3c binds to ADPribose of the host to help $\mathrm{CoV}$ in resisting host innate immunity $^{21}$. Besides, ORF7a protein binds to bone marrow matrix antigen 2 and inhibits its activity by blocking its glycosylation process ${ }^{22}$.

Among others, 3C-like protease (3CLpro), a chymotrypsin-like cysteine protease, was found to be the most useful due to its role in the mutation of SARS-CoV by inducing autolytic cleavage of polyproteins ppla/1ab (ref. 23). Also, 3CLpro was found to cleave the polyprotein at 11 sites with conserved Gln at the P1 position, which was found to be a required condition for efficient cleavage ${ }^{24}$. Papain-like protease (PLpro) was also found as an important target since it plays a vital role in the replication of $\mathrm{CoV}$. In addition to its role in the processing of viral polyprotein, it strips ubiquitin and interferon-stimulated gene-15 from host cell proteins to aid $\mathrm{CoV}$ in its evasion of the host innate immune response. Hence, this target has an additional advantage over 3CLpro to inhibit dysregulation of signalling cascades in infected cells which might be responsible for the death of healthy cells nearby $^{25}$.
$\mathrm{CoV}$ helicase, a non-structural protein, is also considered to be a key target for drug development in this category, particularly against viral replication. This protein is a cleavage product of $\mathrm{pplab}$, which binds to the $5^{\prime}$ overhang and moves in the $5^{\prime} \rightarrow 3^{\prime}$ polarity to bring about negative supercoiling of dsRNA or dsDNA ${ }^{26}$. Apart from the above line of treatments, vaccination represents the preferred line of defence against viral infections due to its higher specificity compared to chemotherapeutic drugs. Immunogenic viral antigens such as the S protein in combination with potent adjuvants such as 3-deacylated monophosphoryl lipid-A or QS21 saponins from Quillaja saponaria may induce either humoral- or cell-mediated immunity by stimulating B-cells as well as $\mathrm{CD}^{+} \mathrm{T}$ cells ${ }^{17}$. In mice, a DNA vaccine encoding the spike $(\mathrm{S})$ glycoprotein of SARS-CoV induced T-cell immunity and neutralizing antibodies, suggesting DNA vaccination as a powerful strategy against SARS-CoV ${ }^{27}$. Moreover, since patients recovering from SARS developed neutralizing antibodies effective in preventing infection, immunotherapy with neutralizing monoclonal antibodies represents a promising approach ${ }^{17}$. Besides these virus proteins, host proteins can also be potential targets, as these provide an attachment site for a virus to enter into the host cells. Such a critical enzyme is the angiotensin-converting enzyme 2, which has been proved by many studies to be the specific receptor for the spike RBD of SARS-CoV-2. Hence, potential $\mathrm{CoV}$ therapeutic drugs can be developed by inhibiting key proteins involved in different pathways.

\section{Natural compounds with anti-CoV activity}

Among other treatments, numerous molecules have been screened against SARS-CoV, MERS-CoV and other CoVs; many of them showed strong activity even at very low concentration ${ }^{28}$. Till date, hundreds of purified natural molecules together with their source extracts have been studied particularly for their anti-SARS-CoV activity $^{29}$. A number of compounds, including scutellarein ${ }^{30}$, tentrandrin $^{31}$, cepharanthine ${ }^{31}$, and betulonic acid ${ }^{32}$ were found to exhibit anti-CoV effects at very low $\mathrm{IC}_{50}$ values even with $<1 \mu \mathrm{M}$ concentration. Earlier studies suggested that natural molecules or their analogues were stronger than synthetic ones. Various mechanism-based studies showed that there is no certain pattern in the structures exhibiting anti-CoV activity because there is a diversity in the active molecules which include alkaloids, flavonoids, terpenoids, anthraquinones, saponins, polypeptides, steroids, tannins and lignans, among others. However, some studies proved that specific structure skeleton and site of substitution were responsible for the activity. In this direction, many coumarin derivatives found in Saposhnikovia divaricata showed activity against porcine epidemic diarrhoea virus, an enveloped single-stranded RNA coronavirus. Structure-activity relationship study 
Table 1. Natural molecules having anti-SARS-CoV activity

\begin{tabular}{|c|c|c|}
\hline Class of compounds & Compound & Natural source \\
\hline Alkaloids & $\begin{array}{l}\text { Berbamine } \\
\text { Cepharanthine } \\
\text { Emetine } \\
\text { Fangchinoline } \\
\text { Lycorine } \\
\text { Papaverine } \\
\text { Reserpine } \\
\text { Tetrandrine } \\
\text { Tylophorine } \\
\text { 7-Methoxycryptopleurine }\end{array}$ & $\begin{array}{l}\text { Berberis amurensis } \\
\text { Stephania cepharantha } \\
\text { Carapichea ipecacuanha } \\
\text { Stephania tetrandra } \\
\text { Lycoris radiate } \\
\text { Papaver somniferum } \\
\text { Rauvolfia serpentine } \\
\text { Stephania tetrandra } \\
\text { Tylophora indica } \\
\text { Tylophora indica }\end{array}$ \\
\hline Flavonoids & $\begin{array}{l}\text { Amentoflavone } \\
\text { Apigenin } \\
\text { Bavachinin } \\
\text { Broussochalcone A } \\
\text { Chrysin } \\
\text { Corylifol A } \\
\text { Diplacone } \\
\text { Gallocatechin gallate } \\
\text { Hesperetin } \\
\text { Isobavachalcone } \\
\text { Juglanin } \\
\text { Luteolin } \\
\text { Mimulone } \\
\text { Myricetin } \\
\text { Neobavaisoflavone } \\
\text { Papyriflavonol A } \\
\text { Procyanidins A2 and B1 } \\
\text { Quercetin } \\
\text { Scutellarein } \\
\text { Theaflavin-3,3'-digallate } \\
\text { Tomentins A-E } \\
\text { (-)-Catechin gallate } \\
\text { 3'-O-Methyldiplacol } \\
\text { 3-Isotheaflavin-3-gallate } \\
\text { 4'-O-methylbavachalcone }\end{array}$ & $\begin{array}{l}\text { Torreya nucifera } \\
\text { Chamaemelum nobile } \\
\text { Psoralea corylifolia } \\
\text { Broussonetia papyrifera } \\
\text { Passiflora caerulea } \\
\text { Psoralea corylifolia } \\
\text { Paulownia tomentosa } \\
\text { Camellia sinensis } \\
\text { Isatis indigotica } \\
\text { Psoralea corylifolia } \\
\text { Polygonum aviculare } \\
\text { Reseda luteola } \\
\text { Paulownia tomentosa } \\
\text { Myrica nagi } \\
\text { Psoralea corylifolia } \\
\text { Broussonetia papyrifera } \\
\text { Cinnamomum verum } \\
\text { Quercus robur } \\
\text { Scutellaria lateriflora } \\
\text { Camellia sinensis } \\
\text { Paulownia tomentosa } \\
\text { Camellia sinensis } \\
\text { Paulownia tomentosa } \\
\text { Camellia sinensis } \\
\text { Psoralea corylifolia }\end{array}$ \\
\hline Terpenoids & $\begin{array}{l}\text { Betulinic acid } \\
\text { Betulonic acid } \\
\text { Ferruginol } \\
\text { Miltirone } \\
\text { Saikosaponins A, B }, \mathrm{C} \text { and D } \\
\text { Tanshinone I }\end{array}$ & $\begin{array}{l}\text { Betula pubescens } \\
\text { Eucalyptus globules } \\
\text { Sequoia sempervirens } \\
\text { Rosmarinus officinalis } \\
\text { Bupleurum chinense } \\
\text { Salvia miltiorrhiza }\end{array}$ \\
\hline Anthraquinones & $\begin{array}{l}\text { Aloe-emodin } \\
\text { Emodin } \\
\text { Rhein }\end{array}$ & $\begin{array}{l}\text { Aloe ferox } \\
\text { Rheum emodi } \\
\text { Rheum rhabarbarum }\end{array}$ \\
\hline Saponins & $\begin{array}{l}\text { Aescin } \\
\text { Glycyrrhizin }\end{array}$ & $\begin{array}{l}\text { Aesculus hippocastanum } \\
\text { Glycyrrhiza glabra }\end{array}$ \\
\hline Polypeptides & $\begin{array}{l}\text { Hitachimycin } \\
\text { Valinomycin }\end{array}$ & $\begin{array}{l}\text { Streptomyces scabriporus } \\
\text { Streptomyces spp. }\end{array}$ \\
\hline Steroids & $\begin{array}{l}\text { Ginsenoside-Rb1 } \\
\beta \text {-Sitosterol }\end{array}$ & $\begin{array}{l}\text { Panax ginseng } \\
\text { Vitis vinifera }\end{array}$ \\
\hline Tannins & $\begin{array}{l}\text { Cinnamtannin B1 } \\
\text { Tannic acid } \\
\text { Tetra- } O \text {-galloyl- } \beta \text {-D-glucose }\end{array}$ & $\begin{array}{l}\text { Cinnamomum verum } \\
\text { Quercus infectoria } \\
\text { Phyllanthus emblica }\end{array}$ \\
\hline Lignans & $\begin{array}{l}\text { Hinokinin } \\
\text { Savinin }\end{array}$ & $\begin{array}{l}\text { Chamaecyparis obtuse } \\
\text { Pterocarpus santalinus }\end{array}$ \\
\hline
\end{tabular}

(Contd) 
Table 1. (Contd)

\begin{tabular}{lll}
\hline Class of compounds & \multicolumn{1}{c}{ Compound } & \multicolumn{1}{c}{ Natural source } \\
\hline Miscellaneous & Chaetochromin & Chaetomium spp. \\
& Cinanserin & Houttuynia cordata \\
& Curcumin & Curcuma longa \\
& Indigo & Indigofera tinctoria \\
Kazinol F & Broussonetia papyrifera \\
& Lutein & Tropaeolum majus \\
& Psoralidin & Psoralea corylifolia \\
& Sinefungin & Streptomyces spp. \\
& Sinigrin & Isatis indigotica \\
& Stictic acid & Usnea articulate \\
\hline
\end{tabular}

revealed that substitution at $\mathrm{C}-8$ position could be responsible for the antiviral activity ${ }^{33}$.

These molecules showed anti-CoV activity via multiple mechanisms such as inhibition of 3CLpro, PLpro, interaction of SARS-CoV S protein and ACE2, viral polymerase, virus replication/cell division, viral attachment and penetration stages ${ }^{29}$. Besides, these were found to block virus to host cell binding, 3 a channel and viral entry to host cells. Table 1 provides a summary of selected molecules with anti-SARS-CoV activity.

Table 1 reveals that flavonoids are the most active compounds, perhaps due to hydroxyl substitution in their structure. The alkaloids are the second most active class, followed by terpenoids and anthraquinones. Although all the above molecules were found active against SARS$\mathrm{CoV}$, a few of them have been reported to be promising with a very low concentration ${ }^{30-32}$. Their mechanisms of action were also established in various in vitro studies ${ }^{29}$. Many of them are already approved drugs for other uses. Hence, a few most active molecules belonging to different chemical classes with their effective concentrations and the possible mechanisms are discussed here. Figure 2 shows their chemical structures.

\section{Stictic acid}

Stictic acid (1) is a bioactive compound found in many lichens, including Usnea articulate and Lobaria pulmonaria. This compound showed antiviral activity in virusinfected CRFK cells by inhibiting 3CLpro of feline infectious peritonitis virus (FIPV), a mutated form of the parental enteric form of feline enteric coronavirus, at the concentration $<50 \mu \mathrm{M}$. It also showed activity to inhibit penetration of virus to the host cell. The activity was found more effective than that of ribavirin $(<50 \mu \mathrm{M})$, which was used as a positive control. Stictic acid also inhibited FIPV replication in CRFK cells after viral infection. The $\mathrm{EC}_{50}$ value was measured at $21.83 \mu \mathrm{M}$, while the SI value was calculated to be 17.04 (ref. 34). Besides, at an $\mathrm{IC}_{50}$ value of $<50 \mu \mathrm{M}$, compound 1 was found to produce potential effect against HIV-1 integrase ${ }^{35}$.

Wassman et al. ${ }^{36}$ found that $\mathbf{1}$ has the potential to react with Cys141 within the cysteine triad of tumour suppres- sor protein p53. As cysteine is also present in 3CLpro of SARS-CoV as the nucleophilic active site in the catalytic dyad (Cys144/His41), hence there is a possibility that $\mathbf{1}$ can also inhibit 3CLpro of coronavirus.

\section{Lycorine}

Lycorine (2), an alkaloid isolated from the stem cortex of Lycoris radiata (L'Hér.) Herb., showed potent in vitro activity against SARS-CoV with an $\mathrm{EC}_{50}$ value of $15.7 \mathrm{nM}$. Its $50 \%$ cytotoxic concentration $\left(\mathrm{CC}_{50}\right)$ was calculated to be 14.98 and $18.81 \mu \mathrm{M}$ against the Vero E6 and HepG2 cell lines respectively, with a selective index of $>900$. Interferon- $\alpha$ was used as a standard, which showed inhibitory effects on virus-induced cytopathic effect with $\mathrm{EC}_{50}$ of $660.3 \mathrm{IU} / \mathrm{ml}$ and $\mathrm{CC}_{50}$ of $>10,000 \mathrm{IU} / \mathrm{ml}$ (ref. 37). This compound was also used against normal Vero E6 and human HepG2 cell lines to evaluate its toxicity. The results showed that it was safe for further use as it showed a $\mathrm{CC}_{50}$ value of $14.98 \mu \mathrm{M}$ (ref. 37). However, the mechanism of action was not elucidated as the study did not evaluate the interaction of lycorine with proteins and antigens of the virus. It inhibited the replication of HCoV-OC43, HCoV-NL63 and MERS-CoV in BHK-21 cells with $\mathrm{EC}_{50}$ values of $0.15,0.47$ and $1.63 \mu \mathrm{M}$ respectively, whereas the $\mathrm{CC}_{50}$ values were recorded at $4.37,3.81$ and $3.14 \mu \mathrm{M}$ respectively ${ }^{38}$. The compound also showed activity against mouse hepatitis virus (MHV)-A59, a $\beta-\mathrm{CoV}$, with $\mathrm{EC}_{50}$ and $\mathrm{CC}_{50}$ values of 0.31 and $3.51 \mu \mathrm{M}$ respectively. Besides, it inhibited the human enterovirus-71 (EV71) infection in mice. The results showed that it reduced mortality, clinical scores and pathological changes in the muscles of experimental animals by inhibiting viral replication at a dose of $0.4 \mathrm{mg} / \mathrm{kg}$ (ref. 39).

\section{Myricetin}

Myricetin (3), a common flavonoid distributed in many families, including Myricaceae and Anacardiaceae, has been found active against Rauscher leukaemia virus (RLV), HIV and SARS-CoV ${ }^{40}$. It displayed activity 

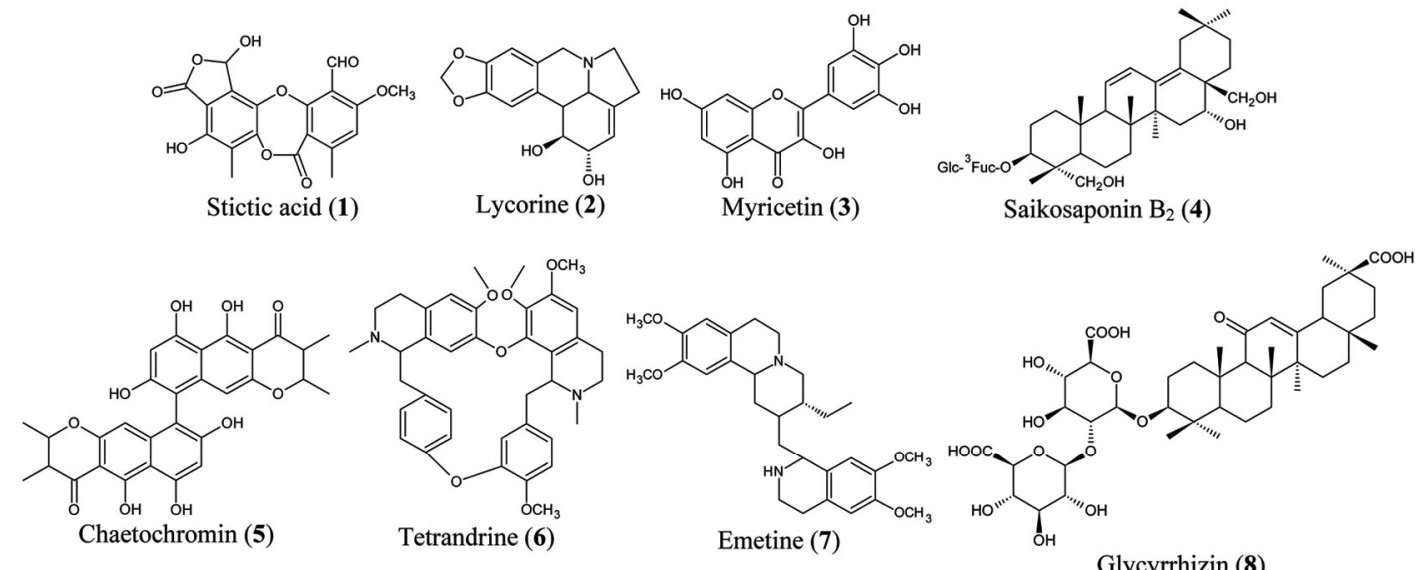

Glycyrrhizin (8)<smiles>Nc1ncnc2c1ncn2C1OC(CC(N)CCC(N)C(=O)O)[C@@H](O)[C@H]1O</smiles>

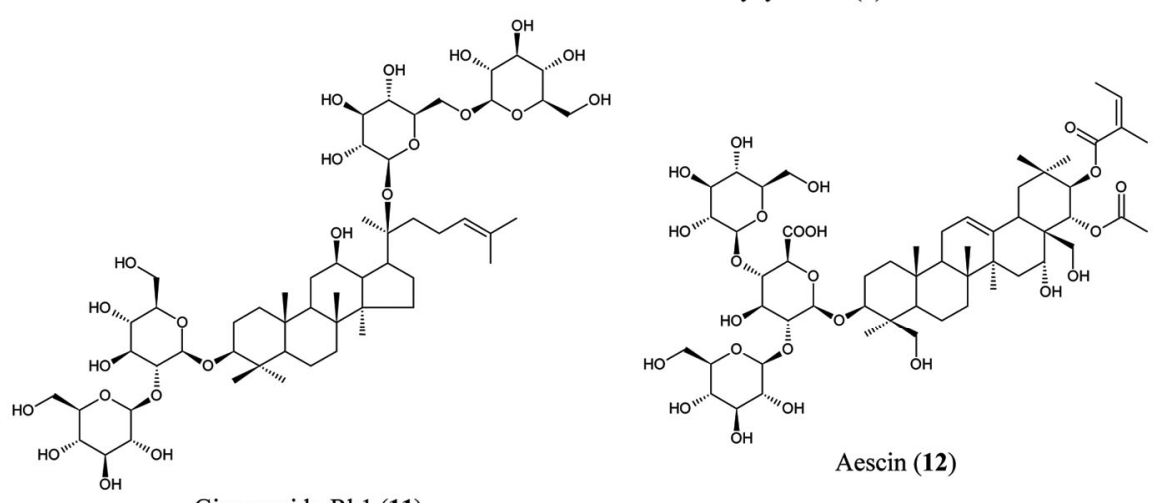

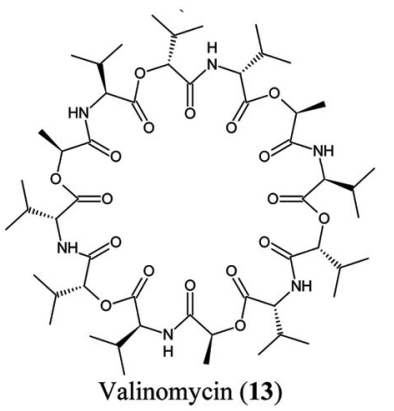

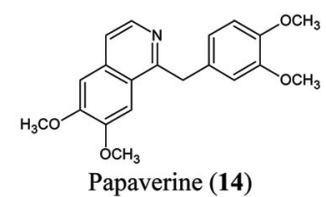

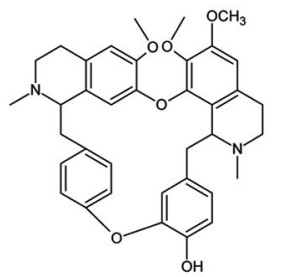

Berbamine (16)<smiles>COc1ccc2c3c([nH]c2c1)C1CC2C(CC(OC(=O)c4cc(OC)c(OC)c(OC)c4)[C@H](OC)C2C(=O)O)CN1CC3</smiles>

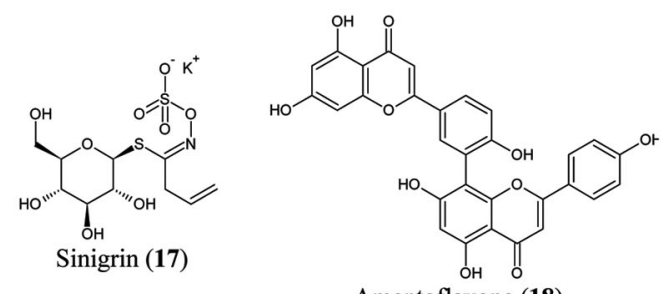

Amentoflavone (18)

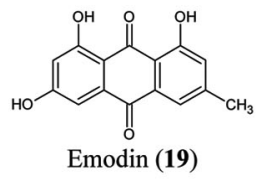

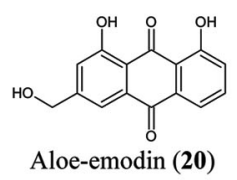

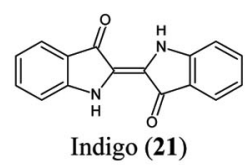<smiles>CC(C)CCCCc1ccccc1C(C)C(C)CCc1ccccc1</smiles>

Cinanserin (22)

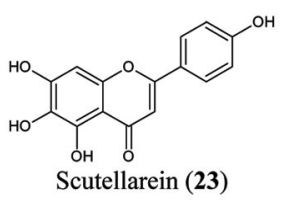

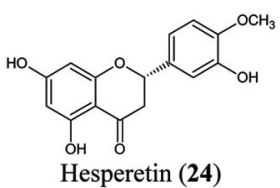

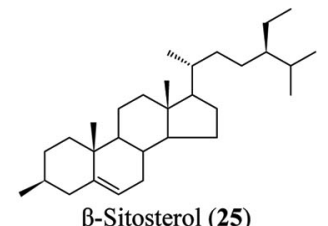

Figure 2. Chemical structures of important anti-SARS-CoV molecules from natural origin. 
against SARS-CoV and inhibited its helicase protein by affecting the ATPase activity, with an $\mathrm{IC}_{50}$ value of $2.71 \mu \mathrm{M}$. The helicase activity was, however, not affected by the treatment of myricetin. Compound $\mathbf{3}$ was found to be safe for further use as it did not show cytotoxicity in MCF10A cells at $2 \mu \mathrm{M}$ (ref. 30). The study also suggested that 3 can directly interact with ATP/ADP-binding pocket of coronavirus helicase protein ${ }^{30}$. Besides, myricetin-3-O- $\beta$-D-glucopyranoside obtained from Camellia sinensis was found as a possible molecule to inhibit 3 CLpro of SARS-CoV-2 via a docking study ${ }^{41}$.

\section{Saikosaponin $B_{2}$}

Triterpenoid glycosides, saikosaponins $\mathrm{A}, \mathrm{B}_{2}, \mathrm{C}$ and $\mathrm{D}$, found in many plant species, including Bupleurum chinense DC, Heteromorpha arborescens (Spreng.) Cham. \& Schltdl., and Scrophularia scorodonia L. have been found to have antiviral effects against a number of pathogens such as human immunodeficiency virus, measles, influenza virus, herpes simplex virus (HSV), varicellazoster virus and $\mathrm{HCoV}-229 \mathrm{E}$ (ref. 42). At concentrations of $25 \mu \mathrm{mol} / \mathrm{l}$, saikosaponins $\mathrm{A}, \mathrm{B}_{2}, \mathrm{C}$ and $\mathrm{D}$ showed $\mathrm{HCoV}-229 \mathrm{E}$ inhibition activity by $67 \%, 100 \%, 58 \%$ and $62 \%$ respectively, whereas the $\mathrm{EC}_{50}$ values were recorded at $8.6,1.7,19.9$ and $13.2 \mu \mathrm{mol} / 1$ respectively. Actinomycin $\mathrm{D}$, a positive control showed activity with $\mathrm{EC}_{50}$ value of $0.02 \mu \mathrm{mol} / 1$. Saikosaponin $B_{2}(4)$ was found to better inhibit $\mathrm{HCoV}-229 \mathrm{E}$ when used before the adsorption of the virus. Besides, the compound at $6 \mu \mathrm{mol} / 1$ also effectively prevented the attachment and penetration of the virus into host cells ${ }^{42}$.

It is interesting to note that all tested saikosaponins were found nontoxic for normal lung MRC-5 cells at a concentration of $2.5 \mu \mathrm{mol} / 1$, as no change in morphology and density was noticed in the cells. Furthermore, cell viability was recorded $>60 \%$ when the concentration was increased to $25 \mu \mathrm{mol} / 1$. No visible changes in cell morphology or cell density were observed at the concentrations tested ${ }^{42}$.

\section{Chaetochromin}

Chaetochromin (5), an antidiabetic drug, first isolated from a fungal species of Chaetomium, showed inhibitory effect on recombinant FIPV 3CLpro with $\mathrm{EC}_{50}$ values of 1.19 and $4.86 \mu \mathrm{M}$ during pre- and post-viral entry respectively. The cytotoxicity showed by the compound against CRFK cells was measured with a $\mathrm{CC}_{50}$ value of $10.53 \mu \mathrm{M}$. The results were found more effective than those of lopinavir, a potent protease inhibitor ${ }^{34}$. Chemically, this compound has two stereoisomers namely chaetochromin A and B, and their comparison of bioactivity is not known. Hence, this drug is given as a mixture rather than an isolated isomer.

\section{Tetrandrine}

Tetrandrine (6), isolated from Stephania tetrandra S. Moore, was earlier tested for its activity against Ebola virus and found to inhibit penetration of virus to the host cells in an in vitro study. Moreover, it inhibited Ebola virus-induced infection of human macrophages in vivo ${ }^{43}$. This compound produced inhibitory effects against the multiplication of HCoV-OC43, HCoV-NL63, MERS$\mathrm{CoV}$, and MHV-A59 with $\mathrm{EC}_{50}$ values of 0.29, 2.05, 12.68 , and $4.81 \mu \mathrm{M}$ respectively, in BHK-21 cells. Also, the $\mathrm{CC}_{50}$ values were measured to be $>20 \mu \mathrm{M}$ against all tested viruses ${ }^{38}$. It inhibited the death of HCoV-OC43infected MRC-5 human lung cells at the early stage of infection. The suppression of virus replication and inhibition of S- and N-protein expression were also recorded during the study at $\mathrm{IC}_{50}$ value of $295.6 \mathrm{nM}$ and SI value $>40$. It is interesting to note that 6 did not show cytotoxicity up to the concentration of $10 \mu \mathrm{M}$ (ref. 31).

In view of its effect against SARS-CoV, Henan Provincial People's Hospital (China) has started clinical trials on this drug against COVID-19, and has already found encouraging results up to phase III trials; and phase IV trials are in progress ${ }^{44}$. This study targeted to enrol at least 60 COVID-19 patients with mild to severe neocoronary pneumonia. Tetrandrine tablets were given to them together with standard treatment regimens to reduce the clinical progress, improve prognosis and reduce the incidence of pulmonary fibrosis.

\section{Emetine}

Emetine (7), a drug obtained from the roots of Carapichea ipecacuanha, was found effective in inhibiting the replication and penetration of four different CoVs, viz. HCoV-OC43, HCoV-NL63, MERS-CoV and MHV-A59 in $\mathrm{BHK}-21$ cells. The $\mathrm{EC}_{50}$ values for these viruses were $0.30,1.43,0.34$, and $0.12 \mu \mathrm{M}$ while the $\mathrm{CC}_{50}$ values were $2.69,3.63,3.08$, and $3.51 \mu \mathrm{M}$ respectively, in BHK-21 cells $^{38}$. The study also confirmed that emetine can inhibit the replication of both DNA and RNA viruses.

\section{Glycyrrhizin}

Glycyrrhizin (8), purified from the roots of Glycyrrhiza glabra L., was evaluated for its anti-SARS-CoV activity in vitro, and found that it inhibited virus infection with an $\mathrm{EC}_{50}$ value of $300 \mu \mathrm{g} / \mathrm{ml}$. The compound inhibited replication in Vero cells with a selectivity index of 67. During the virus adsorption to Vero cells $\mathrm{EC}_{50}$ was calculated to be $2400 \mu \mathrm{g} / \mathrm{ml}$, while after virus adsorption the $\mathrm{EC}_{50}$ value was found to be $600 \mu \mathrm{g} / \mathrm{ml}$, which showed that the compound is comparably more effective when added after virus adsorption. The $\mathrm{CC}_{50}$ value was measured to $>20,000 \mu \mathrm{g} / \mathrm{ml}$ for all experimental conditions ${ }^{45}$. 
The compound inhibited both adsorption and penetration of $\mathrm{CoV}$, which is usually an initial phase of the replication cycle of a virus. The expression of virus antigens was found considerably lower in the cells treated with $1000 \mu \mathrm{g} / \mathrm{ml}$ concentration, while replication was completely blocked at a concentration of $4000 \mu \mathrm{g} / \mathrm{ml}$. As far as the mechanism is concerned, it induced NOS in Vero cells and virus replication was inhibited after adding $\beta$-NONOate, a nitrous oxide donor to the culture medium ${ }^{45}$. Although its antiviral mechanism is not clear enough, its role against $\mathrm{PKC}, \mathrm{CK} 2, \mathrm{AP} 1$ and $\mathrm{NF} \kappa \mathrm{B}$ has been well-established.

Previously, compound $\mathbf{8}$ was also tested for its activity against the replication of flaviviruses at different concentrations. The compound was found effective against viruses with $\mathrm{EC}_{50}$ values ranging from 316 to $625 \mu \mathrm{g} / \mathrm{ml}$ (ref. 46). Glycyrrhizin was found non-cytotoxic up to $2500 \mu \mathrm{g} / \mathrm{ml}$, as no inhibition in cell growth was observed at this concentration. Hoever et al. ${ }^{47}$ reported that after introducing 2 -acetamido- $\beta$-D-glucopyranosylamine into the glycosidic chain of $\mathbf{8}$, its anti-CoV activity was found to increase by 10 -fold than that of compound 8 itself. On the other hand, the activity was increased up to 70 -fold after forming its amides and conjugates with two amino acids and one $\mathrm{COOH}$ group at $\mathrm{C}-30$. These structures were, however, found to be more toxic than that of pure glycyrrhizin.

Pharmacokinetics studies of $\mathbf{8}$ showed that it hydrolyses to $18 \beta$-glycyrrhetinic acid when taken via the oral route. The hydrolysed product, after getting absorbed in the gut, metabolises to $3 \beta$-monoglucuronyl- $18 \beta$-glycyrrhetinic acid in the liver, and finally reaches the blood. The metabolite then circulates in the bloodstream. A clinical study with six participants showed that $0.31-0.67 \%$ metabolite was excreted by urine when a dose of $600 \mathrm{mg}$ of 8 was given orally ${ }^{48}$. Higher doses at 354 and 430 per day were clinically proven to be effective against 37 patients of SARS-CoV. The compound could treat all associated-symptoms like dry cough, chest distress and dyspnea $^{49}$.

\section{Sinefungin}

Sinefungin (9), a nucleoside found in Streptomyces, inhibited the activities of N7-MTase and 2'O-MTases of Vaccinia virus with $\mathrm{IC}_{50}$ values of 12.0 and $39.5 \mathrm{nM}$ respectively ${ }^{50}$. At $\mathrm{IC}_{50}$ value of $55 \mathrm{nM}$, it also inhibited fungal N7-MTase in an in vivo model ${ }^{51}$. Its activity against the SARS-CoV N7-MTase was evaluated using MT-yeast, MT-human and MT-SARS, and found that the compound repressed the growth of these yeast strains at a concentration of $100 \mu \mathrm{M}$. The strongest activity was shown against MT-yeast, and the study found that it is a broad-spectrum inhibitor against N7-MTases of yeasts, humans and $\mathrm{CoVs}^{52}$.

\section{Hitachimycin}

Hitachimycin (10), a well-known bioactive compound found in Streptomyces scabriporus, exhibited FIPV 3CLpro inhibitory activity in CRFK cells. The FIPV 3CLpro has been found responsible for poly-protein processing in $\mathrm{CoV}$ during its replication. The $\mathrm{EC}_{50}$ values for pre-viral entry, post-viral entry and prophylactic antiviral activity were found at $3.83,4$ and $16.22 \mu \mathrm{M}$ respectively. This activity was found more effective than that of ribavirin which was used as a reference drug. The compound was found safe as it showed cytotoxicity with a $\mathrm{CC}_{50}$ value of $56.87 \mu \mathrm{M}$ (ref. 34).

\section{Ginsenoside-Rb1}

Ginsenoside-Rb1 (11) isolated from Panax ginseng, was found to have anti-SARS-CoV activity in Vero cells at the concentration of $100 \mu \mathrm{M}$ (ref. 53). This molecule showed no toxicity in NIH-3T3 cells even at $100 \mu \mathrm{M}$. Cell viability was not affected during and after the experiment $^{54}$. Its antiviral activity was also evaluated against $\mathrm{H} 1 \mathrm{~N} 1$ virus and found that its administration at 1 and $2 \mathrm{mg} / \mathrm{ml}$ prior to the infection in mice reduced weight loss and complete protection over lethal infection ${ }^{55}$. Besides, it has the ability to inhibit replication of the virus. The overall results suggested that compound $\mathbf{1 1}$ may be further used as a lead molecule for antiviral drug discovery against SARS-CoV-2 after obtaining its toxicity and bioavailability profile.

\section{Aescin}

Aescin (12), a bioactive found in Aesculus hippocastanum L., produced antiviral effect against SARS-CoV in Vero E6 cells with $\mathrm{EC}_{50}$ value of $6.0 \mu \mathrm{M}$ and $\mathrm{CC}_{50}$ value of $15 \mu \mathrm{M}$. Based on the results, the selectivity index (SI) was calculated to be 2.5 (ref. 53). This molecule has been least studied for its antiviral activity in comparison to other molecules considered here. Since compound 12 showed remarkable activity with lesser concentration, its further use in higher models may produce better results.

\section{Valinomycin}

Valinomycin (13), a fungus-derived dodecadepsipeptide found in Streptomyces species, showed inhibitory activity against SARS-CoV with an $\mathrm{EC}_{50}$ value of $0.85 \mu \mathrm{M}$ and $\mathrm{CC}_{50}$ value of $68 \mu \mathrm{M}(\mathrm{SI}=80)$. SARS virus-infected Vero E6 cells were treated with valinomycin and found that it inhibited the multiplication and penetration of the virus $^{53}$. Its activity against $\mathrm{HCoV}-\mathrm{OC} 43, \mathrm{HCoV}-\mathrm{NL} 63$, MERS-CoV and MHV-A59 has been established with $\mathrm{EC}_{50}$ values of $4.43,1.89,6.07$, and $6.78 \mu \mathrm{M}$ and $\mathrm{CC}_{50}$ 
values of $6.15,4.12,5.88$, and $5.11 \mu \mathrm{M}$ respectively in BHK-21 cells ${ }^{38}$.

\section{Papaverine}

Papaverine (14), naturally occurring in the capsules of Papaver somniferum, is an established antispasmodic drug. This alkaloid showed anti-SARS-CoV activity against the replication of $\mathrm{HCoV}-\mathrm{OC} 43$, HCoV-NL63, MERS-CoV and MHV-A59 with $\mathrm{EC}_{50}$ values of 1.61, 7.32, 9.45 and $11.46 \mu \mathrm{M}$ respectively, in BHK-21 cells. The respective $\mathrm{CC}_{50}$ values were recorded at 12.11, 11.71, 11.98 and 12.44 $\mu \mathrm{M}$ (ref. 38).

\section{Reserpine}

Reserpine (15), the well-known alkaloidal drug naturally found in Rauvolfia serpentina (L.) Benth. ex Kurz, was shown to have anti-SARS-CoV activity. The SI calculated for this compound was 7.3 with $\mathrm{EC}_{50}$ and $\mathrm{CC}_{50}$ values of $3.4 \mu \mathrm{M}$ and $25 \mu \mathrm{M}$ respectively. Compound $\mathbf{1 5}$ was also found to inhibit virus penetration into Vero E6 cells $^{53}$. As this drug is already in clinical use, its trial against COVID-19 can be conducted by following earlier trials mainly for dose determination.

\section{Berbamine}

Berbamine (16), a natural alkaloid found in Berberis amurensis and other species of the Berberidaceae family, was screened for its antiviral efficacy. This compound was found effective against the replication of $\mathrm{HCoV}$ OC43, HCoV-NL63, MERS-CoV and MHV-A59 with $\mathrm{EC}_{50}$ values of $1.48,9.46,13.14$ and $10.91 \mu \mathrm{M}$ respectively. A $\mathrm{CC}_{50}$ value of $>20 \mu \mathrm{M}$ against all the above viruses was also measured in an in vitro study in BHK-21 cells $^{38}$. The molecule was only studied for its preliminary antiviral activity, the mechanism of action was not evaluated. Moreover, toxicity studies are lacking; hence, such studies are required before using it on higher models.

\section{Sinigrin}

Sinigrin (17) is a glucosinolate which is found in many species of family Brassicaceae, including Isatis indigotica Fort. It showed activity against 3CLpro which is responsible for mediating proteolytic processing of replicase polypeptides (pp1-a and pp1-ab) into functional proteins of the virus. The $\mathrm{IC}_{50}$ value for cell-based cleavage activity of this compound was measured at $217 \mu \mathrm{M}$, with $\mathrm{CC}_{50}$ value for Vero cell death at $>10,000 \mu \mathrm{M}$. It effectively blocked the cleavage process of 3CLpro. In addition, it was found non-toxic to Vero cells as it showed a $\mathrm{CC}_{50}$ value of $>10,000 \mu \mathrm{M}$ (ref. 56).

\section{Amentoflavone}

Amentoflavone (18), isolated from the leaves of Torreya nucifera, has been found to inhibit SARS-CoV 3CLpro with an $\mathrm{IC}_{50}$ value of $8.3 \mu \mathrm{M}$. The structure-activity relationship study showed that an apigenin moiety at position C- $3^{\prime}$ is responsible for the inhibitory activity of 3CLpro (ref. 57). Apigenin, luteolin and quercetin were used to understand the structure-activity relationship and found that apigenin showed 3CLpro inhibitory activity by $40 \%$ at $200 \mu \mathrm{M}$, while luteolin and quercetin showed activity with $\mathrm{IC}_{50}$ values of 20.2 and $23.8 \mu \mathrm{M}$ respectively. This is interesting because these compounds are also AhR ligands. Thus, it might be useful to test other AhR ligands as well.

\section{Emodin}

Emodin (19), one of the active compounds of Rheum emodi, furnished antiviral activity against most of the pathogenic viruses like hepatitis-B, $-\mathrm{C}$, HSV and $\mathrm{CoV}$. Particularly against hepatitis B, it showed activity by inhibiting the DNA replication and HBsAg secretion of the virus in $\mathrm{G} 2.2 .15$ cells with an $\mathrm{IC}_{50}$ value of $21 \mu \mathrm{g} / \mathrm{ml}$ (ref. 58). This activity was also confirmed by Dang et al. ${ }^{59}$ using mice models at a dose of $287.95 \mathrm{mg} / \mathrm{kg} / \mathrm{day}$ for 21 days. Emodin also inhibited influenza A virus (IAV) replication, reduced expressions of TLR2/3/4/7, MyD88 and TRAF6, decreased phosphorylations of $\mathrm{p} 38 / \mathrm{JNK}$ MAPK and nuclear translocation of NF- $\kappa \mathrm{B}$ p 65 induced by IAV (ref. 60).

Interestingly, its activity against SARS-CoV is highly effective as it was found to block the interaction of $\mathrm{CoV}$ spike protein with ACE-2 and to inhibit the infectivity of coronavirus spike proteinpseudo-typed retrovirus in Vero E6 cells. It showed inhibition of the interaction between $\mathrm{S}$ protein and ACE2 by $60 \%$ at a concentration of $400 \mu \mathrm{M}$. The $\mathrm{IC}_{50}$ value for this activity was measured at $200 \mu \mathrm{M}$ (ref. 61). Emodin inhibited the 3a ion channel of $\mathrm{HCoV}-\mathrm{OC} 43$ with a $\mathrm{K}_{1 / 2}$ value of $20 \mu \mathrm{M}$. The virusinduced cytopathic effect was found to reduce with a concentration of $8 \mu \mathrm{M}$, moreover, it decreased the number and size of plaques in the RD cells after virus infection $^{62}$.

\section{Aloe-emodin}

Aloe-emodin (20), an anthraquinone found in many plant species, including Aloe vera, Cassia angustifolia and Rheum emodi, was shown to inhibit the cleavage activity of SARS-CoV 3CLpro in cell-free and cell-based assays 
with $\mathrm{IC}_{50}$ values of 132 and $366 \mu \mathrm{M}$ respectively. The $\mathrm{CC}_{50}$ value of cell death was measured at $11,592 \mu \mathrm{M}$ (ref. 56).

\section{Indigo}

Indigo (21), more popularly known for its dyeing properties, is a natural compound found in Indigofera tinctoria, Isatis indigotica, etc. This compound showed inhibitory effect on cell-free and cell-based cleavage activity of SARS-CoV 3CLpro with $\mathrm{IC}_{50}$ values of 300 and $752 \mu \mathrm{M}$ respectively. Indigo was found non-toxic to Vero cells with a $\mathrm{CC}_{50}$ value of $7375 \mu \mathrm{M}$ (ref. 56).

\section{Cinanserin}

Cinanserin (22), found in Houttuynia cordata, is a wellknown serotonin antagonists that was also found effective against murine $\mathrm{CoV}$. At an $\mathrm{IC}_{50}$ value of $5 \mu \mathrm{M}$, this was found to inhibit the catalytic activity of 3CLpro of SARS$\mathrm{CoV}$ and $\mathrm{HCoV}-229 \mathrm{E}$. This molecule has already undergone clinical trials during 1960 and showed encouraging results; hence, it has been considered for further use ${ }^{63}$. As cinanserin has been already evaluated for its efficacy and safely in humans, it can be tested against SARS-CoV-2 without considering toxicity issues.

\section{Scutellarein}

Scutellarein (23), a flavone occurs in Scutellaria lateriflora, was found to inhibit SARS-CoV helicase protein by affecting the ATPase activity of nsP13 by more than $90 \%$ at a concentration of $10 \mu \mathrm{M}$. The $\mathrm{IC}_{50}$ value of scutellarein measured for this activity was $0.86 \mu \mathrm{M}$. The molecule was found to be non-toxic against MCF10A cells up to a concentration of $2 \mu \mathrm{M}$. The study also suggested that the molecule can directly interact with ATP/ADP-binding pocket of the SARS-CoV helicase protein ${ }^{30}$.

\section{Hesperetin}

Hesperetin (24), a flavonoid found in many citrus fruits and other plants such as Isatis indigotica, inhibited the cleavage activity of SARS-CoV 3CLpro in cell-free assay with $\mathrm{IC}_{50}$ value of $60 \mu \mathrm{M}$, whereas $\mathrm{CC}_{50}$ value was recorded at $2718 \mu \mathrm{M}$ (ref. 56). It also showed inhibitory effects on Sindbis virus with an $\mathrm{IC}_{50}$ value of $68 \mu \mathrm{M}$, using the plaque assay ${ }^{64}$. Although limited studies have been done with this interesting molecule, including some docking studies, it needs further exploration with advanced research using higher models. As the molecule has not yet been studied against SARS-CoV-2, its effect against COVID-19 can be evaluated.

\section{$\beta$-Sitosterol}

$\beta$-Sitosterol (25) is a well-known phytosterol found in most plant species showing diverse pharmacological activities. It blocked the cleavage process of SARS-CoV 3 CLpro with an $\mathrm{IC}_{50}$ value of $1210 \mu \mathrm{M}$ in Vero cells. It was found non-toxic to Vero cells with a $\mathrm{CC}_{50}$ value of $1475 \mu \mathrm{M}$ (ref. 56).

\section{Toxicity studies}

An extensive survey of the literature revealed that most of the molecules discussed here are non-toxic at lower doses. Interestingly, few of them are already in use as medicines for other purposes. Many of these molecules such as glycyrrhizin, aescin and reserpine have been found safe under an optimum concentration and used clinically for several years in original or modified forms ${ }^{53}$. Although used frequently, glycyrrhizin in higher doses and/or for a long duration may cause severe adverse effects, including pseudoaldosteronism, which is mainly due to its metabolite, viz. $3 \beta$-monoglucuronyl$18 \beta$-glycyrrhetinic acid $^{48}$. Its use is recommended only under medical supervision. Similarly, reserpine, a US Food and Drug Administration-approved drug often prescribed in combination with hydrochlorothiazide for hypertension, is safe and can be taken under medical supervision $^{65}$. Emodin, at lower doses of 0.6 and $2.5 \mathrm{mg} / \mathrm{ml}$, showed no toxicity; however, at a higher dose of $6 \mathrm{mg} / \mathrm{ml}$, it caused reduction in the average foetal body weight per litter in mice. Emodin also caused toxic effects in rats and mice when used at a dose of $60 \mathrm{mg} / \mathrm{ml}$ or higher ${ }^{66}$. The toxicity of myricetin has also been evaluated using both in vitro and in vivo experiments. Most of these studies suggested that this molecule is safe for clinical research. An in vivo study by Yang et al. ${ }^{67}$ did not reveal any toxic symptoms when a dose of $1000 \mathrm{mg} / \mathrm{kg}$ was intraperitoneally administered to mice.

Among the several toxicity studies on $\beta$-sitosterol ${ }^{68}$, an important study by Paniagua-Pérez et al. ${ }^{69}$ found that this molecule is neither cytotoxic nor genotoxic to mice up to $\mathrm{LD}_{50}$ of $1000 \mathrm{mg} / \mathrm{kg}$. Malini and Vanithakumari ${ }^{70}$ reported that its subcutaneous treatment to rats at $10 \mathrm{mg} / \mathrm{kg}$ for two months was safe, as no toxic signs appeared either externally nor internally, which was confirmed by microscopic studies of liver and kidney. Besides the functions of liver and kidney, all other blood parameters, including haemoglobin, glucose, bilirubin, glutamic oxaloacetic transaminase and glutamic pyruvic transaminase were also found normal. However, the study found a drastic fall in the blood protein levels at $10 \mathrm{mg} / \mathrm{kg}$, albeit only in males, whereas a dose-dependent decrease in the blood cholesterol levels was recorded after treatment with $\beta$-sitosterol ${ }^{70}$. This phytosterol was also used clinically to treat conditions of prostate enlargement, enrolling 519 
males in a study. Although it did not significantly reduce prostate size in comparison to the control group, its role in improving urinary symptoms and flow measures was encouraging $^{71}$. A randomized clinical trial of plant sterols containing $\beta$-sitosterol found that the dose of $1.6 \mathrm{~g}$ per day to 26 subjects for one month significantly reduced hypercholesterolemia ${ }^{72}$. Similarly, hesperetin was shown clinically to inhibit the activity of acetyl-CoA acetyltransferase (ACAT)-1 and ACAT-2 genes, reduce the activity of microsomal triglyceride transfer protein and upregulate the low-density lipoproteins receptor. It also reduced cholesterol level in human subjects ${ }^{73}$. Hence, based on the preclinical and clinical studies, these molecules can be considered safe and evaluated against SARS-CoV using higher experimental models.

Beyond the dyeing properties, indigo showed diverse biological activities, including in vitro anti-SARS-CoV. This molecule has been evaluated for its toxicity in animals and found that it was safe in lower doses, but it had low oral toxicity at an $\mathrm{LD}_{50}$ of $5 \mathrm{~g} / \mathrm{kg}$ (ref. 74). On the other hand, amentoflavone was tested for its toxicity in human umbilical vein endothelial cells and recorded an $\mathrm{LD}_{50}$ of $290 \mu \mathrm{M}$ (ref. 75). Hence, based on its toxicity profile, it has been used in rat models at $40 \mathrm{mg} / \mathrm{kg}$ (orally) or $10 \mathrm{ml} / \mathrm{kg}$ (i.v.) to evaluate antitumour activity.

Thus, earlier studies have revealed that most of the above-mentioned natural molecules are safe under certain doses/concentrations. These molecules can be evaluated for their anti-SARS-CoV activity both in animals and humans, as there is no toxicity concern with any of these natural entities. On the other hand, a few molecules considered in this study have limited toxicity data. These compounds have either not been evaluated for their toxicity or only in vitro studies were performed to measure their toxic profile. Hence, it is necessary to evaluate the toxicity of such molecules before using them in further studies.

\section{Opportunities and challenges}

Plant natural products have long been used as a valuable source of molecules with diverse therapeutic potential. Plant-derived natural products represent an important basket for the identification of novel drug candidates. The biggest advantage of drug discovery from plant natural products is that sometimes well-recognized ethnopharmacological information about the traditional medicinal use of whole plants or their extracts is available, which can provide us with the knowledge of the type of natural product effective in therapeutics ${ }^{76}$. When compared to synthetic and combinatorial compounds, plant-derived natural products have unique structural characteristics, high chemical diversity, biochemical specificity and other molecular properties that make them attractive targets as lead structures for drug discovery in new disease targets.
In the recent past, many reports have been published on drug discovery from natural products with key challenges and possible solutions, as they have been found important scaffolds in searching new drugs, including flavonoids, terpenoids, polyketides, phenylpropanoids and alkaloids $^{77-79}$. Despite the great potential of plant natural products to be used as new drug candidates, there are many challenges, including their complex isolation and characterization methods, and poor yield in most of the cases $^{80}$.

Previous studies suggested that natural molecules are non-toxic in nature when consumed in lower amounts because most of them are already part of our daily diet, e.g. tea polyphenols. The main challenges in using molecules such as emodin and scutellarin as drugs are their poor solubility and bioavailability. The shorter gastrointestinal transit time and poor membrane permeability affect the absorption of a drug into the GIT. Hence, it is an important point to be considered for the sustainable release of an oral drug in GIT for its maximum utilization $^{81}$. There are several studies associated with improvement in the bioavailability of natural molecules. In this direction, Yang et al. ${ }^{82}$ prepared a nanosuspension to increase the bioavailability and dissolution rate of scutellarin to improve its drug-like properties. Hence, using advanced tools like nanotechnology can help improve the drug-like properties of molecules with poor bioavailability.

Combination therapy using more than one agent or treatment procedure, has been well-accepted globally mainly against infectious diseases caused by microorganisms $^{83}$. It has been noticed that there are many compounds which are either inactive or poorly active against infection when used alone, but in combination with other molecules, they show stronger activity against the same infection. A common example of this is the treatment of tuberculosis with a combination of ethambutol, isoniazid, pyrazinamide and rifampin ${ }^{84}$. Hence, a combination of more than one natural compound is a good choice, which needs profound research. In addition, the route/delivery of a drug plays a key role in the line of treatment against a particular pathological condition. There are several drugs which show different efficacies when administered through different routes; for example, diclofenac which is used as oral, topical or injection ${ }^{85}$. Selected molecules having poor absorption or poor membrane permeability through oral route can be tested via the intravenous or intramuscular route. These routes are also important if a patient is not in a position to take medicines through the mouth. In some cases, other routes like nasal, ear or eye are also helpful, in which sometimes there is need of a carrier to target the drug to a particular site ${ }^{86}$.

Apart from the above-mentioned points, another key challenge in drug development is mimicking the results of lower to higher experimental models. In many cases, molecules showing activity in docking studies are inactive 


\section{REVIEW ARTICLE}

in in vitro or ex vivo models, and similarly, the active molecules of an in vitrolex vivo model show no activity in the in vivo model. Unlike the in vitro/ex vivo system, this happens because of the complex physiology of animals or humans, which involves multiple mechanisms. Furthermore, the physiology of humans is different from that of animals, and hence, a molecule exhibiting activity in an animal model (in vivo) may be inactive in humans (clinical trials). In the present study, most of the molecules were tested for their anti-SARS-CoV activity using in vitro models. The activity on higher models has either not been studied or may be under progress. Therefore, by considering the above challenges, research on higher models, including clinical trials should be conducted on active molecules using advanced tools and techniques. Studies for improving the drug-like properties, including pharmacokinetics, of the most active molecules should be conducted to develop a drug against SARS-CoV.

\section{Conclusion}

The COVID-19 pandemic has pushed the world to a state never witnessed before, as thousands of people have died, and many more are under critical care. As no effective treatment is yet available for $\mathrm{CoV}$, scientists from all over the world are looking for possible solutions against this pandemic. Studies confirmed that SARS-CoV-2 has similarity to the earlier known SARS-CoV in several ways, and hence, a few anti-SARS-CoV drugs have also been considered for the prophylaxis and management of COVID-19 pneumonia. Previous research revealed that these molecules, including myricetin, tetrandrine, glycyrrhizin, aescin, reserpine, emodin and scutellarein have the potential to inhibit the essential proteases, helicase and viral proteins of SARS-CoV at very low concentrations. These molecules also have the capability to inhibit penetration of the virus to the host cell. Hence, there is tremendous scope for developing new drug leads from antiSARS-CoV against anti-SARS-CoV-2 because, besides similarity in most of the proteins, SARS-CoV-2 has almost $80 \%$ identical genome sequence to SARS-CoV.

1. Lin, L. T., Hsu, W. C. and Lin, C. C., Antiviral natural products and herbal medicines. J. Tradit. Complement. Med., 2014, 4(1), 24-35.

2. van der Hoek, L., Human coronaviruses: what do they cause? Antivir. Ther., 2007, 12(4 Pt B), 651-658.

3. Geller, C., Varbanov, M. and Duval, R. E., Human coronaviruses: insights into environmental resistance and its influence on the development of new antiseptic strategies. Viruses, 2012, 4(11), 3044-3068.

4. World Health Organization, 2019 Middle East respiratory syndrome coronavirus (MERS-CoV), 11 March 2019; www.who.int (accessed on 29 March 2020).

5. Paules, C. I., Marston, H. D. and Fauci, A. S., Coronavirus infections-more than just the common cold. JAMA, 2020, 10.1001/jama.2020.0757, advance online publication.
6. Hilgenfeld, R., From SARS to MERS: crystallographic studies on coronaviral proteases enable antiviral drug design. FEBS J., 2014, 281(18), 4085-4096.

7. McBride, R., van Zyl, M. and Fielding, B. C., The coronavirus nucleocapsid is a multifunctional protein. Viruses, 2014, 6(8), 2991-3018.

8. Li, F., Structure, function, and evolution of coronavirus spike proteins. Annu. Rev. Virol., 2016, 3(1), 237-261.

9. Lu, R. et al., Genomic characterization and epidemiology of 2019 novel coronavirus: implications for virus origins and receptor binding. Lancet, 2020, 395(10224), 565-574.

10. Ahmed, S. F., Quadeer, A. A. and McKay, M. R., Preliminary identification of potential vaccine targets for the COVID-19 coronavirus (SARS-CoV-2) based on SARS-CoV immunological studies. Viruses, 2020, 12(3), 254.

11. Chen, J., Pathogenicity and transmissibility of 2019-nCoV-a quick overview and comparison with other emerging viruses. Microbes Infect., 2020, 22(2), 69-71.

12. Monteil, V. et al., Inhibition of SARS-CoV-2 infections in engineered human tissues using clinical-grade soluble human ACE2. Cell, 2020, 181, 1-9.

13. Li, G. et al., Coronavirus infections and immune responses. J. Med. Virol., 2020, 92(4), 424-432.

14. Chen, Y., Liu, Q. and Guo, D., Emerging coronaviruses: genome structure, replication, and pathogenesis. J. Med. Virol., 2020, 92(4), 418-423.

15. Wu, K. L., Peng, G. Q., Wilken, M., Geraghty, R. J. and Li, F., Mechanisms of host receptor adaptation by severe acute respiratory syndrome coronavirus. J. Biol. Chem., 2012, 287, 8904-8911.

16. Nasri, H. and Shirzad, H., Toxicity and safety of medicinal plants. J. Herb. Med. Pharmacol., 2013, 2(2), 21-22.

17. Kumar, V., Jung, Y. S. and Liang, P. H., Anti-SARS coronavirus agents: a patent review (2008-present). Expert Opin. Ther. Pat., 2013, 23(10), 1337-1348.

18. Ivanov, K. A. and Ziebuhr, J., Human coronavirus 229E nonstructural protein 13: characterization of duplex-unwinding, nucleoside triphosphatase, and RNA 5'-triphosphatase activities. J. Virol., 2004, 78(14), 7833-7838.

19. Millet, J. K. and Whittaker, G. R., Host cell proteases: critical determinants of coronavirus tropism and pathogenesis. Virus Res., 2015, 202, 120-134.

20. Narayanan, K., Huang, C., Lokugamage, K., Kamitani, W., Ikegami, T., Tseng, C. T. and Makino, S., Severe acute respiratory syndrome coronavirus NSP1 suppresses host gene expression, including that of type I interferon, in infected cells. J. Virol., 2008, 82(9), 4471-4479.

21. Forni, D., Cagliani, R., Mozzi, A., Pozzoli, U., Al-Daghri, N., Clerici, M. and Sironi, M., Extensive positive selection drives the evolution of nonstructural proteins in lineage $\mathrm{C}$ betacoronaviruses. J. Virol., 2016, 90(7), 3627-3639.

22. Taylor, J. K. et al., Severe acute respiratory syndrome coronavirus ORF7a inhibits bone marrow stromal antigen 2 virion tethering through a novel mechanism of glycosylation interference. J. Virol., 2015, 89(23), 11820-11833.

23. Kuo, C. J., Chi, Y. H., Hsu, J. T. and Liang, P. H., Characterization of SARS main protease and inhibitor assay using a fluorogenic substrate. Biochem. Biophys. Res. Commun., 2004, 318(4), 862867.

24. Fang, S. G., Shen, H., Wang, J., Tay, F. P. and Liu, D. X., Proteolytic processing of polyproteins $1 \mathrm{a}$ and $1 \mathrm{ab}$ between non-structural proteins 10 and 11/12 of coronavirus infectious bronchitis virus is dispensable for viral replication in cultured cells. Virology, 2008, 379(2), 175-180.

25. Báez-Santos, Y. M., St John, S. E. and Mesecar, A. D., The SARS-coronavirus papain-like protease: structure, function and inhibition by designed antiviral compounds. Antivir. Res., 2015, 115, 21-38. 
26. Adedeji, A. O. et al., Mechanism of nucleic acid unwinding by SARS-CoV helicase. PLoS ONE, 2012, 7(5), e36521.

27. Yang, Z. Y., Kong, W. P., Huang, Y., Roberts, A., Murphy, B. R., Subbarao, K. and Nabel, G. J., A DNA vaccine induces SARS coronavirus neutralization and protective immunity in mice. Nature, 2004, 428(6982), 561-564.

28. Li, H., Liu, S. M., Yu, X. H., Tang, S. L. and Tang, C. K., Coronavirus disease 2019 (COVID-19): current status and future perspectives. Int. J. Antimicrob. Agents, 2020, 105951, advance online publication.

29. Islam, M. T., Sarkar, C., El-Kersh, D. M., Jamaddar, S., Uddin, S J., Shilpi, J. A. and Mubarak, M. S., Natural products and their derivatives against coronavirus: a review of the non-clinical and pre-clinical data. Phytother. Res., 2020, 10.1002/ptr.6700; advance online publication.

30. Yu, M. S. et al., Identification of myricetin and scutellarein as novel chemical inhibitors of the SARS coronavirus helicase, NSP13. Bioorg. Med. Chem. Lett., 2012, $22(12), 4049-4054$.

31. Kim, D. E. et al., Natural bis-benzylisoquinoline alkaloidstetrandrine, fangchinoline, and cepharanthine, inhibit human coronavirus OC43 infection of MRC-5 human lung cells. Biomolecules, 2019, 9(11), 696.

32. Wen, C. C. et al., Specific plant terpenoids and lignoids possess potent antiviral activities against severe acute respiratory syndrome coronavirus. J. Med. Chem., 2007, 50(17), 40874095.

33. Yang, J. L., Ha, Y. K. W. and Oh, W. K., Discovery of inhibitory materials against PEDV corona virus from medicinal plants. Jpn. J. Vet. Res., 2016, 64(Suppl. 1), S53-S63.

34. Theerawatanasirikul, S., Kuo, C. J., Phetcharat, N. and Lekcharoensuk, P., In silico and in vitro analysis of small molecules and natural compounds targeting the $3 \mathrm{CL}$ protease of feline infectious peritonitis virus. Antivir. Res., 2020, 174, 104697.

35. Neamati, N. et al., Depsides and depsidones as inhibitors of HIV-1 integrase: discovery of novel inhibitors through 3D database searching. J. Med. Chem., 1997, 40(6), 942-951.

36. Wassman, C. D. et al., Computational identification of a transiently open L1/S3 pocket for reactivation of mutant p53. Nature Commun., 2013, 4, 1407.

37. Li, S. Y. et al., Identification of natural compounds with antiviral activities against SARS-associated coronavirus. Antivir. Res., 2005, 67(1), 18-23.

38. Shen, L. et al., High-throughput screening and identification of potent broad-spectrum inhibitors of coronaviruses. J. Virol., 2019, 93(12), e00023-19.

39. Liu, J., Yang, Y., Xu, Y., Ma, C., Qin, C. and Zhang, L., Lycorine reduces mortality of human enterovirus 71 -infected mice by inhibiting virus replication. Virol. J., 2011, 8, 483.

40. Semwal, D. K., Semwal, R. B., Combrinck, S. and Viljoen, A., Myricetin: a dietary molecule with diverse biological activities. Nutrients, 2016, 8(2), 90.

41. Ul Qamar, M. T., Alqahtani, S. M., Alamri, M. A. and Chen, L. L., Structural basis of SARS-CoV-2 3CLpro and anti-COVID-19 drug discovery from medicinal plants. J. Pharm. Anal., 2020, 10.1016/j.jpha.2020.03.009, advance online publication

42. Cheng, P. W., Ng, L. T., Chiang, L. C. and Lin, C. C., Antiviral effects of saikosaponins on human coronavirus $229 \mathrm{E}$ in vitro. Clin. Exp. Pharmacol. Physiol., 2006, 33(7), 612-616.

43. Sakurai, Y. et al., Ebola virus. Two-pore channels control Ebola virus host cell entry and are drug targets for disease treatment. Science, 2015, 347(6225), 995-998.

44. ClinicalTrials.gov, Tetrandrine tablets used in the treatment of COVID-19 (TT-NPC). ClinicalTrials.gov Identifier: NCT04308317; last updated on 16 March 2020; https://clinicaltrials.gov/ct2/ show/NCT04308317

45. Cinatl, J., Morgenstern, B., Bauer, G., Chandra, P., Rabenau, H. and Doerr, H. W., Glycyrrhizin, an active component of liquorice roots, and replication of SARS-associated coronavirus. Lancet, 2003, 361(9374), 2045-2046.

46. Crance, J. M., Scaramozzino, N., Jouan, A. and Garin, D., Interferon, ribavirin, 6-azauridine and glycyrrhizin: antiviral compounds active against pathogenic flaviviruses. Antivir. Res., 2003, 58(1), 73-79.

47. Hoever, G. et al., Antiviral activity of glycyrrhizic acid derivatives against SARS-coronavirus. J. Med. Chem., 2005, 48(4), $1256-1259$.

48. Glavač, N. K. and Kreft, S., Excretion profile of glycyrrhizin metabolite in human urine. Food Chem., 2012, 131(1), 305-308.

49. Lu, H., Huo, N., Wang, G., Li, H., Nie, L. and Xu, X., Clinical observation of therapeutic effect of compound glycyrrhizin on SARS. China Pharm., 2003, 10, 610-612.

50. Pugh, C. S., Borchardt, R. T. and Stone, H. O., Sinefungin, a potent inhibitor of virion mRNA(guanine-7-)-methyltransferase, mRNA(nucleoside-2'-)-methyltransferase, and viral multiplication. J. Biol. Chem., 1978, 253(12), 4075-4077.

51. Chrebet, G. L., Wisniewski, D., Perkins, A. L., Deng, Q., Kurtz, M. B., Marcy, A. and Parent, S. A., Cell-based assays to detect inhibitors of fungal mRNA capping enzymes and characterization of sinefungin as a cap methyltransferase inhibitor. J. Biomol. Screen, 2005, 10(4), 355-364.

52. Sun, Y. et al., Yeast-based assays for the high-throughput screening of inhibitors of coronavirus RNA cap guanine-N7-methyltransferase. Antivir. Res., 2014, 104, 156-164.

53. Wu, C. Y. et al., Small molecules targeting severe acute respiratory syndrome human coronavirus. Proc. Natl. Acad. Sci. USA, 2004, 101(27), 10012-10017.

54. Kang, S., Im, K., Kim, G. and Min, H., Antiviral activity of 20(R)ginsenoside $\mathrm{Rh} 2$ against murine gammaherpesvirus. J. Ginseng Res., 2017, 41(4), 496-502.

55. Dong, W., Farooqui, A., Leon, A. J. and Kelvin, D. J., Inhibition of influenza A virus infection by ginsenosides. PLOS ONE, 2017, 12(2), e0171936.

56. Lin, C. W. et al., Anti-SARS coronavirus 3C-like protease effects of Isatis indigotica root and plant-derived phenolic compounds. Antivir. Res., 2005, 68(1), 36-42.

57. Ryu, Y. B. et al., Biflavonoids from Torreya nucifera displaying SARS-CoV 3CL(pro) inhibition. Bioorg. Med. Chem., 2010, 18(22), 7940-7947.

58. Shuangsuo, D., Zhengguo, Z., Yunru, C., Xin, Z., Baofeng, W., Lichao, Y. and Yan'an, C., Inhibition of the replication of hepatitis B virus in vitro by emodin. Med. Sci. Monit., 2006, 12(9), BR302-BR306.

59. Dang, S. S., Jia, X. L., Song, P., Cheng, Y. A., Zhang, X., Sun, M. Z. and Liu, E. Q., Inhibitory effect of emodin and Astragalus polysaccharide on the replication of HBV. World J. Gastroenterol., 2009, 15(45), 5669-5673.

60. Dai, J. P. et al., Emodin inhibition of influenza A virus replication and influenza viral pneumonia via the Nrf2, TLR4, p38/JNK and NF-kappaB pathways. Molecules, 2017, 22(10), 1754.

61. Ho, T. Y., Wu, S. L., Chen, J. C., Li, C. C. and Hsiang, C. Y., Emodin blocks the SARS coronavirus spike protein and angiotensinconverting enzyme 2 interaction. Antivir. Res., 2007, 74(2), 92-101.

62. Schwarz, S., Wang, K., Yu, W., Sun, B. and Schwarz, W., Emodin inhibits current through SARS-associated coronavirus 3a protein. Antivir. Res., 2011, 90(1), 64-69.

63. Chen, L. et al., Cinanserin is an inhibitor of the 3C-like proteinase of severe acute respiratory syndrome coronavirus and strongly reduces virus replication in vitro. J. Virol., 2005, 79(11), 70957103.

64. Paredes, A., Alzuru, M., Mendez, J. and Rodríguez-Ortega, M., Anti-sindbis activity of flavanones hesperetin and naringenin. Biol. Pharm. Bull., 2003, 26(1), 108-109.

65. Wang, B., Choudhry, N. K., Gagne, J. J., Landon, J. and Kesselheim, A. S., Availability and utilization of cardiovascular fixed-dose 


\section{REVIEW ARTICLE}

combination drugs in the United States. Am. Heart J., 2015 , 169(3), 379-386.e1.

66. Jahnke, G. D., Price, C. J., Marr, M. C., Myers, C. B. and George, J. D., Developmental toxicity evaluation of emodin in rats and mice. Birth Defects Res. B, 2004, 71(2), 89-101.

67. Yang, Y. et al., SNARE-wedging polyphenols as small molecular botox. Planta Med., 2012, 78(3), 233-236.

68. Bin Sayeed, M. S., Karim, S., Sharmin, T. and Morshed, M. M., Critical analysis on characterization, systemic effect and therapeutic potential of beta-sitosterol: a plant-derived orphan phytosterol. Medicines, 2016, 3(4), 29.

69. Paniagua-Pérez, R. et al., Genotoxic and cytotoxic studies of betasitosterol and pteropodine in mouse. J. Biomed. Biotechnol., 2005, $\mathbf{2 0 0 5}(3)$, 242-247.

70. Malini, T. and Vanithakumari, G., Rat toxicity studies with betasitosterol. J. Ethnopharmacol., 1990, 28(2), 221-234.

71. Wilt, T. J., Ishani, A., MacDonald, R., Stark, G., Mulrow, C. D and Lau, J., Beta-sitosterols for benign prostatic hyperplasia. Cochrane Database Syst. Rev., 2000, 2, CD001043.

72. Rudkowska, I., Abumweis, S. S., Nicolle, C. and Jones, P. J., Cholesterol-lowering efficacy of plant sterols in low-fat yogurt consumed as a snack or with a meal. J. Am. Coll. Nutr., 2008, 27(5), $588-595$.

73. DrugBank, Hesperetin. Drug created on 13 June 2005; 12 June 2020; https://www.drugbank.ca/drugs/DB01094

74. Steingruber, E., Indigo and indigo colorants. In Ullmann's Encyclopedia of Industrial Chemistry, Wiley-VCH, Weinheim, Germany, 2004.

75. Tarallo, V. et al., The biflavonoid amentoflavone inhibits neovascularization preventing the activity of proangiogenic vascular endothelial growth factors. J. Biol. Chem., 2011, 286(22), 1964119651.

76. Kinghorn, A. D., Pan, L., Fletcher, J. N. and Chai, H., The relevance of higher plants in lead compound discovery programs. J. Nat. Prod., 2011, 74(6), 1539-1555.
77. Davison, E. K. and Brimble, M. A., Natural product derived privileged scaffolds in drug discovery. Curr. Opin. Chem. Biol., 2019, $\mathbf{5 2}, 1-8$.

78. Harvey, A., Edrada-Ebel, R. and Quinn, R., The re-emergence of natural products for drug discovery in the genomics era. Nature Rev. Drug Discov., 2015, 14, 111-129.

79. Dias, D. A., Urban, S. and Roessner, U., A historical overview of natural products in drug discovery. Metabolites, 2012, 2(2), 303336.

80. Atanasov, A. G. et al., Discovery and resupply of pharmacologically active plant-derived natural products: a review. Biotechnol. $A d v ., 2015,33(8), 1582-1614$.

81. Homayun, B., Lin, X. and Choi, H. J., Challenges and recent progress in oral drug delivery systems for biopharmaceuticals. Pharmaceutics, 2019, 11(3), 129.

82. Yang, X. et al., Nanosuspension development of scutellarein as an active and rapid orally absorbed precursor of its BCS class IV glycoside scutellarin. J. Pharm. Sci., 2014, 103(11), 3576-3584.

83. Maurya, I. K., Semwal, R. B. and Semwal, D. K., Combination therapy against human infections caused by Candida species. In Combination Therapy against Multi-drug Resistance (eds Wani, M. Y. and Ahmad, A.), Elsevier, The Netherlands, 2020, pp. 81-94.

84. Danckwerts, M. P., Ebrahim, S. and Pillay, V., Pharmaceutical formulation of a fixed-dose anti-tuberculosis combination. Int. J. Tuberc. Lung Dis., 2003, 7(3), 289-297.

85. Chung, C. H., The use of injectable nonsteroidal antiinflammatory drugs in local accident and emergency practice. Hong Kong J. Emerg. Med., 2017, 9(2), 65-71.

86. FDA, Route of administration. US Food and Drug Administration, updated on 14 November 2017; https:/www.fda.gov/drugs/datastandards-manual-monographs/route-administration

Received 12 May 2020; revised accepted 6 July 2020

doi: $10.18520 / \mathrm{cs} / \mathrm{v} 119 / \mathrm{i} 5 / 757-770$ 